\title{
Pembenahan Tata Kelola Ikatan Ahli Boga Dewan Pengurus Cabang Kabupaten Lombok Barat
}

\author{
Hermanto*, Thatok Asmony, Prayitno Basuki \\ Fakultas Ekonomi dan Bisnis Universitas Mataram, Mataram, Indonesia
}

\section{Article history}

Received: 06-11-2020

Revised: 20-11-2020

Accepted: 24-11-2020

*Corresponding Author: Hermanto,

Fakultas Ekonomi dan Bisnis Universitas Mataram, Mataram Nusa Tenggara Barat, Indonesia

Email:

hermanto57@gmail.com

\begin{abstract}
The activity of improving the governance of the Ikaboga Branch Management Board (DPC) of West Lombok Regency aims to provide knowledge for the administrators of the Ikaboga DPC, West Lombok Regency regarding good organizational governance. Another objective of this activity is to provide knowledge on how to compile financial reports, especially bookkeeping and provide training to make financial reports for administrators so that the organization becomes good governance. In the end, this activity is expected to provide an understanding for the administrators of the Ikaboga DPC, West Lombok Regency about how good governance and the administrators of the Ikaboga DPC in West Lombok Regency are able to manage finances and make financial reports so as to improve better governance. This training activity will be aimed at administrators of the Ikaboga DPC, West Lombok Regency. The implementation of activities is carried out with the approach of providing material relevant to improving governance.
\end{abstract}

Keywords: governance; financial; statements; ikaboga

Abtrak: Kegiatan pembenahan tata kelola Dewan Pengurus Cabang (DPC) Ikaboga Kabupaten Lombok Barat ini bertujuan untuk memberikan pengetahuan bagi pengurus DPC Ikaboga Kabupaten Lombok Barat mengenai tata kelola organisasi yang baik. Tujuan lain dari kegiatan ini adalah memberikan pengetahuan mengenai bagaimana cara menyusun laporan keuangan terutama pencatatan pembukuan serta memberikan pelatihan untuk membuat laporan keuangan bagi pengurus sehingga organisasi menjadi good governance. Pada akhirnya kegiatan ini diharapkan dapat memberikan pemahaman bagi pengurus DPC Ikaboga Kabupaten Lombok Barat tentang bagaimana tata kelola yang baik dan pengurus DPC Ikaboga Kabupaten Lombok Barat mampu mengelola keuangan serta membuat laporan keuangan sehingga meningkatkan tata kelola yang lebih baik. Kegiatan pelatihan ini akan ditujukan pada pengurus DPC Ikaboga Kabupaten Lombok Barat. Pelaksanaan kegiatan dilakukan dengan pendekatan pemberian materi yang relevan dengan peningkatan tata kelola.

Kata Kunci: tata kelola; laporan; keuangan; ikaboga

\section{PENDAHULUAN}

Good Governance adalah suatu tata kelola yang baik yang harus diterapkan untuk mencapai sebuah kesuksesan dalam setiap organisasi, sehingga akan menimbulkan tujuan yang ingin dicapai sesuai dengan yang sudah ditentukan. Saat ini good governance sangat penting, karena good 
governance adalah instrumen untuk mengukur ada atau tidaknya pekerjaan yang mencakup transparansi, profesionalisme, partisipatif, efektif serta efisien dalam bekerja di dalam sebuah organisasi yang dipimpin oleh seorang atasan terhadap pegawai-pegawainya.

Tata kelola organisasi yang baik dibutuhkan untuk mengatur dan mengendalikan hubungan antara pihak manajemen organisasi dengan seluruh pihak yang berkepentingan terhadap organisasi mengenai hak-hak dan kewajiban mereka sesuai dengan visi-misi organisasi. Hal ini bertujuan menciptakan nilai tambah bagi semua pihak yang berkepentingan serta tercapainya tujuan dan program kerja organisasi secara efektif.

Banyak manfaat yang diperoleh dalam melaksanakan tata kelola organisasi, di antaranya adalah sebagai berikut: 1) Meningkatkan kinerja organisasi melalui terciptanya proses pengambilan keputusan yang lebih baik, meningkatkan efisiensi operasional organisasi serta lebih meningkatkan pelayanan kepada pihak yang berkepentingan (stakeholder); 2) Mempermudah diperolehnya dana pembiayaan yang lebih murah dan tidak rigid (karena faktor kepercayaan) yang pada akhirnya akan meningkatkan nilai organisasi (corporate value); dan 3) Meningkatkan kepercayaan investor/donatur untuk menanamkan modalnya. Salah satu penelitian McKinsey \& Company memberi indikasi bahwa para manajer dana di Asia akan membayar 26-30\% lebih untuk saham-saham organisasi yang mempunyai tata kelola organisasi yang baik ketimbang untuk saham-saham organisasi dengan tata kelola organisasi yang meragukan.

Organisasi dapat berjalan dengan baik apabila melaksanakan prinsip dasar tata kelola organisasi yang baik. Prinsip-prinsip tata kelola organisasi disusun secara fleksibel sehingga dapat diimplementasikan bagi segala bentuk organisasi. Prinsip-prinsip tata kelola organisasi yang dimaksud, antara lain: kewajaran (fairness), keterbukaan (transparency), akuntabilitas (accountability), pertanggungjawaban (responsibility), kemandirian (independency).

Dalam prakteknya prinsip tata kelola organisasi yang baik harus dibangun dan dikembangkan secara bertahap dengan melibatkan semua pihak yang berkepentingan. Organisasi harus membangun sistem dan pedoman tata kelola organisasi yang terintegrasi. Karyawan pun harus dibekali pemahaman dan pengetahuan tentang prinsip-prinsip tata kelola organisasi yang baik sesuai dengan apa yang akan dijalankan organisasi. Selain itu, perlu dilakukan pengawasan secara kontinyu terhadap proses-proses yang terjadi dalam sistem tata kelola yang sudah dibuat.

Ikatan Ahli Boga Indonesia (IKABOGA Indonesia) berdiri pada tanggal 3 Desember 1987 yang merupakan wadah tunggal Ahli Boga Indonesia. Pendirian ini merupakan realisasi dari gagasan Subkonsorsium Memasak dan Jasa Boga pada Direktorat Pendidikan Masyarakat Ditjen Diklusepora Departemen Pendidikan Nasional. Sebagai suatu organisasi yang tumbuh dan berkembang dari bawah secara demokrasi maka kesinambungan program kerja selalu diikuti juga dengan kesinambungan kepengurusan. Dalam kaitan ini untuk memenuhi amanat di dalam Anggaran Dasar/Anggaran Rumah Tangga Ikaboga mengenai kepengurusan dan program kerja.

Adapun visi misi IKABOGA adalah membangun masyarakat boga Indonesia yang profesional. Untuk mencapai visinya, IKABOGA Indonesia menyelenggarakan berbagai kegiatan kemasyarakatan yang non politik, mandiri, dan bebas aktif dengan melibatkan masyarakat secara perorangan atau melalui organisasi, serta menggalang kerja sama dengan pemerintah dan dunia usaha.

Salah satu IKABOGA yang memerlukan tata kelola yang baik adalah IKABOGA Kabupaten Lombok Barat. Hal ini dikarenakan pengelolaan keuangan yang masih dirasa kurang termasuk pencatatan serta pembukuan keuangan terutama ketika dilakukan berbagai kegiatan untuk mencapai visi dan misi organisasi. Pencatatan dan pembukuan adalah suatu proses pengumpulan data dan 
informasi keuangan secara rinci. Pencatatan dan pembukuan menjadi sangat penting dilakukan untuk mengetahui perkembangan dalam suatu organisasi. Selain itu juga membantu organisasi dalam mengontrol dana yang masuk terutama saat melakukan kegiatan. Pencatatan dapat dilakukan secara sederhana apabila SDM belum memiliki kemampuan akuntansi atau dengan menggunakan excel sehingga mempermudah pencatatan dan pembukuan. Oleh karena itu pengabdian ini dilakukan pada IKABOGA Kabupaten Lombok Barat sehingga mempermudah dalam mengelola organisasi dengan lebih baik. Berdasarkan analisis situasi diatas, maka dapat dirumuskan permasalahan yaitu 1) Pengelolaan keuangan yang masih dirasa kurang termasuk pencatatan serta pembukuan keuangan terutama ketika dilakukan berbagai kegiatan untuk mencapai visi dan misi organisasi, 2 Kurangnya pengetahun SDM terkait pengelolaan keuangan termasuk pencatatan serta pembukuan dalam berbagai kegiatan yang dilakukan.

\section{METODE}

Adapun metode pelaksanaan kegiatan Pengabdian Pada masyarakat ini dilakukan dengan metode Ceramah, tutorial, dan diskusi. Dengan langkah-langkah kegiatan sebagai berikut :

1. Langkah 1 (Metode Ceramah)

Peserta diberikan penyuluhan tentang pembenahan tata kelola DPC Ikaboga Kabupaten Lombok Barat.

2. Langkah 2 (Metode Tutorial)

Peserta pelatihan diberikan latihan singkat tentang tata kelola dengan praktek secara langsung dengan cara melakukan pendampingan tentang cara membuat laporan keuangan untuk organisasi nirlaba.

3. Langkah 3 (Metode Diskusi)

Peserta diberikan kesempatan untuk menyampaikan dan mendiskusikan permasalahan yang dihadapi dalam tata kelola organisasi yang baik

\section{HASIL DAN PEMBAHASAN}

Kegiatan pengabdian dilakukan di Panti Asuhan Darrus-Shiddiqien NW Merta Paok pada hari Rabu 22 Agustus 2020 pada pukul 10.00 Wita. Peserta pengabdian dihadiri oleh 10 peserta Dewan Pengurus Cabang (DPC) Ikaboga Kabupaten Lombok Barat. Sebelum kegiatan pengabdian dilakukan, tim pengabdian telah melakukan pemberitahuan informasi secara langsung kepada ketua DPC Ikaboga Lobar yang kemudian disampaikan pada setiap anggota Ikaboga Lobar. Selanjutnya kegiatan pengabdian ini dilakukan dengan mempresentasikan materi mengenai pembenahan tata kelola kepada peserta, yang dilanjutkan dengan sesi tanya jawab/diskusi antara pemateri dan peserta pengabdian

Beberapa materi telah dipersiapkan dalam bentuk handout yang dibagikan pada peserta pengabdian yang bertujuan untuk mempermudah peserta dalam memahami pokok bahasan yang akan diberikan oleh pemateri. Pemberian materi ini dilakukan dengan menampilkan slide powerpoint yang secara lengkap akan disajikan pada lampiran. Adapun materi yang diberikan secara garis besar adalah tentang "Pembenahan Tata Kelola".Good governance pada dasarnya adalah suatu konsep yang mengacu kepada proses pencapaian keputusan dan pelaksanaannya yang dapat dipertanggung jawabkan secara bersama. Sebagai suatu konsensus yang dicapai oleh pemerintah, warga negara, dan sektor swasta bagi penyelenggaraan pemerintahaan dalam suatu negara. 
Kunci utama memahami good governance adalah pemahaman atas prinsip-prinsip di dalamnya. Bertolak dari prinsip-prinsip ini akan didapatkan tolak ukur kinerja suatu pemerintahan. Baikburuknya pemerintahan bisa dinilai bila ia telah bersinggungan dengan semua unsur prinsip-prinsip good governance. Menyadari pentingnya masalah ini, prinsip-prinsip good governance diurai satu persatu sebagaimana tertera di bawah ini.

Partisipasi masyarakat dalam proses politik dan perumusan-perumusan kebijakan publik memerlukan sistem dan aturan-aturan hukum. Sehubungan dengan itu, dalam proses mewujudkan cita good governance, harus diimbangi dengan komitmen untuk menegakkan rule of law dengan karakterkarakter antara lain sebagai berikut: Supremasi hukum (the supremacy of law), Kepastian hukum (legal certainty), Hukum yang responsip, Penegakkan hukum yang konsisten dan non-diskriminatif, Indepedensi peradilan. Kerangka hukum harus adil dan diberlakukan tanpa pandang bulu, termasuk di dalamnya hukum-hukum yang menyangkut hak asasi manusia.

Transparansi adalah keterbukaan atas semua tindakan dan kebijakan yang diambil oleh pemerintah. Prinsip transparansi menciptakan kepercayaan timbal-balik antara pemerintah dan masyarakat melalui penyediaan informasi dan menjamin kemudahan di dalam memperoleh informasi yang akurat dan memadai. Tranparansi dibangun atas dasar arus informasi yang bebas. Seluruh proses pemerintahan, lembaga-lembaga dan informasi perlu dapat diakses oleh pihak-pihak yang berkepentingan, dan informasi yang tersedia harus memadai agar dapat dimengerti dan dipantau. Sehingga bertambahnya wawasan dan pengetahuan masyarakat terhadap penyelenggaraan pemerintahan. Meningkatnya kepercayaan masyarakat terhadap pemerintahan, meningkatnya jumlah masyarakat yang berpartisipasi dalam pembangunan dan berkurangnya pelanggaran terhadap peraturan perundang-undangan.

Untuk menunjang prinsip-prinsip yang telah disebutkan di atas, pemerintahan yang baik dan bersih juga harus memenuhi kriteria efektif dan efisien yakni berdaya guna dan berhasil-guna. Kriteria efektif biasanya di ukur dengan parameter produk yang dapat menjangkau sebesar-besarnya kepentingan masyarakat dari berbagai kelompok dan lapisan sosial. Agar pemerintahan itu efektif dan efisien, maka para pejabat pemerintahan harus mampu menyusun perencanaan-perencanaan yang sesuai dengan kebutuhan nyata masyarakat, dan disusun secara rasional dan terukur. Dengan perencanaan yang rasional tersebut, maka harapan partisipasi masyarakat akan dapat digerakkan dengan mudah, karena program-program itu menjadi bagian dari kebutuhan mereka. Proses-proses pemerintahan dan lembaga-lembaga membuahkan hasil sesuai kebutuhan warga masyarakat dan dengan menggunakan sumber-sumber daya yang ada seoptimal mungkin.

Akuntabilitas adalah pertangungjawaban pejabat publik terhadap masyarakat yang memberinya kewenangan untuk mengurusi kepentingan mereka. Para pengambil keputusan di pemerintah, sektor swasta dan organisasi-organisasi masyarakat bertanggung jawab baik kepada masyarakat maupun kepada lembaga-lembaga yang berkepentingan. Bentuk pertanggungjawaban tersebut berbeda satu dengan lainnya tergantung dari jenis organisasi yang bersangkutan. Instrumen dasar akuntabilitas adalah peraturan perundang-undangan yang ada, dengan komitmen politik akan akuntabilitas maupun mekanisme pertanggungjawaban, sedangkan instrumen-instrumen pendukungnya adalah pedoman tingkah laku dan sistem pemantauan kinerja penyelenggara pemerintahan dan sistem pengawasan dengan sanksi yang jelas dan tegas.

Akuntansi adalah seni untuk mencatat, meringkas, menganalisis, dan melaporkan data yang berkaitan dengan transaksi keuangan dalam bisnis atau perusahaan. Untuk praktisi dalam bidang ini disebut dengan akuntan. Akuntansi sendiri juga telah disebut "bahasa bisnis"untuk mengukur hasil 
kegiatan ekonomi dalam organisasi dan menyampaikan informasi ini kepada berbagai pihak, termasuk investor, kreditor, manajemen, dan regulator. Sejarah ilmu akuntansi sudah berusia ribuan tahun dan dapat ditelusuri ke peradaban kuno.Perkembangan awalnya adalah pada Mesopotamia kuno dan terkait erat dengan perkembangan dalam penulisan, penghitungan dan sistem uang.

Akuntansi adalah adalah sekumpulan proses yang berkaitan dengan proses keuangan yang terjadi pada bisnis atau organisasi. Prosesnya terdiri dari mencatat, meringkas, menganalisis, dan melaporkan data. Berikut adalah penjelasan keempat proses tersebut.

\section{Mencatat}

Proses pertama dan terpenting dalam sebuah proses akuntansi adalah pencatatan berbagai transaksi yang dibuat dalam perusahaan. Ini juga dapat disebut sebagai pembukuan yang merupakan proses mengenali transaksi dan memasukannya sebagai catatan. Pembukuan hanya berkaitan dengan segmen pencatatan dan tidak ada yang lain. Dalam akuntansi sendiri biasanya terdiri dari banyak pembukuan guna kepentingan pencatatan yang terperinci. Pemeliharaan prosedur ini terjadi secara sistematis.

Berikut adalah 3 tahap pencatatan transaksi keuangan :

1. Menggunakan sistem yang akan membantu Anda dalam mengelola catatan keuangan.

2. Melacak transaksi keuangan secara terperinci.

3. Menggabungkan laporan untuk menyajikan dalam satu set pada akhir laporan keuangan.

\section{Meringkas}

Data mentah umumnya merupakan hasil pencatatan transaksi. Namun, data mentah ini tidak terlalu penting bagi organisasi. Data mentah tidak memiliki arti yang berarti dalam proses pengambilan keputusan. Jadi setelah melakukan pencatatan transaksi kemudian bisa ditindaklanjuti dengan meringkas.

\section{Pelaporan}

Urusan di perusahaan adalah sepenuhnya tanggung jawab manajemen. Pemilik bisnis harus tahu tentang berbagai operasi yang terjadi dalam perusahaan dan bagaimana perusahaan menggunakan aset. Untuk mengatasi hal ini, pemilik menerima laporan keuangan setiap bulanan, tiga bulanan dan laporan tahunan yang merangkum semua kinerja.

\section{Menganalisa}

Pada akhirnya, menganalisa adalah akhir dari setiap proses yang telah dilakukan. Setelah merekam dan ringkasan, sangat penting untuk menarik kesimpulan dalam sebuah bisnis. Manajemen bertanggung jawab untuk memeriksa poin positif dan negatif. Oleh karena itu, untuk menganalisis semua, akuntansi memperkenalkan konsep perbandingan. Membandingkan laba, penjualan, ekuitas, dan sebagainya satu sama lain untuk menentukan dan menganalisis kinerja, mengambil keputusan dan membuat pertumbuhan suatu organisasi bisnis.

Metode pencatatan setidaknya harus diketahui untuk mempermudah dalam melakukan pencatatan. Ada 2 metode yang dapat digunakan yaitu sistem pembukuan single entry dan sistem pembukuan double entry. Sistem pembukuan single entry adalah bahwa setiap transaksi yang di catat dalam pembukuan dilakukan dengan entri tunggal. Sistem seperti ini biasanya digunakan untuk melaporkan hasil usaha, seperti laporan laba-rugi. Terutama ketika perusahaan ingin melakukan 
pelacakan atas penerimaan kas serta pembayaran tunai. Sedangkan untuk catatan yang berkaitan dengan kewajiban dan aset, umumnya akan dipisahkan pada bagian lain. Sistem pembukuan double entry merupakan sistem akuntansi yang saat ini paling banyak dijadikan dasar dari seluruh aktivitas pembukuan, yang di dalamnya terdapat dua kolom untuk diisi, yaitu debit dan kredit. Metode double entry merupakan metode yang dalam setiap transaksi keuangannya akan menampilkan dua efek secara bersamaan.

Menurut PSAK 45, organisasi nirlaba perlu menyusun setidaknya 4 jenis laporan keuangan sebagai berikut:

1. Laporan posisi keuangan (neraca) pada akhir periode laporan

2. Laporan aktivitas untuk suatu periode pelaporan

3. Laporan arus kas untuk suatu periode pelaporan

4. Catatan atas laporan keuangan

Setelah mendengarkan ceramah tentang pengelolaan keuangan, maka bagian kedua adalah memberikan kesempatan kepada peserta untuk mengajukan pertanyaan dan mendiskusikan secara bersama dengan tim pengabdian. Beberapa pertanyaan yang diajukan adalah sebagai berikut:

1. Organisasi Ikaboga merupakan organisasi tanpa profit (nirlaba), hal-hal apa saja yang harus kami lakukan atau perhatikan dalam mewujudkan good governance itu sendiri?

2. Salah satu untuk melakukan pembenahan tata kelola organisasi adalah dengan mencatat atau melakukan pembukuan, kira-kira laporan apa saja yang harus kami buat?

3. Prinsip tata kelola yang baik yaitu akuntabilitas dan transparansi, bagaimana untuk mewujudkan tata kelola yang baik. Apakah setiap belanja kecil harus dicatat?

Dalam menanggapi pertanyaan dari peserta pengabdian, tim pengabdian memberikan penjelasan terkait pembenahan tata kelola Ikaboga. Berikut adalah ringkasan jawaban atas pertanyaan yang diajukan oleh peserta pengabdian:

1. Good Governance adalah tata kelola pemerintahan yang baik dan sesuai dengan peraturan yang sudah ada.di dalam Good governance itu sendiri memiliki sembilan prinsip yaitu Partisipasi Masyarakat ,Tegaknya Supremasi Hukum, Peduli pada Stakeholder, Berorientasi pada Konsensus, Efektifitas dan Efisiensi, akuntabilitas, transparansi, Partisipasi,Visi Strategis. Faktor yang muncul sehingga menghambat mewujudkan good governance adalah tidak adanya motivasi untuk berprestasi. Dalam beberaoa teori sosiologi disebutkan bahwa gejala yang muncul adalah tidak adanya kemauan untuk berperestasi (melakukan inovasi baru atau mengembangkan inovasi sebelumnya). Untuk mewujudkan tata kelola yang baik tentu saja yang pertama harus ada kemauan dari diri sendiri. Apabila tidak ada keinginan dari diri sendiri tentu saja usaha tidak akan berkembang. Yang kedua yaitu dengan melakukan pencatatan dan pembukuan setiap aktivitas kas keluar dan kas masuk, sehingga modal atau aset dapat selalu diawasi penggunaannya. Organisasi Ikaboga yang terutama organisasi tanpa profit atau laba dapat melakukan pembenahan tata kelola yang dimulai dari pengelolaan keuangannya. Seperti melakukan pencatatan dan pembukuan walaupun transaksi yang dilakukan sedikit. Ikaboga dalam mewujudkan visi dan misi juga dapat membantu masyarakat sekitar dalam meningkatkan ekonomi sekitar dengan bekerja sama dalam melakukan inovasi terkait kuliner. Dari kegiatan-kegiatan tersebut dapat dicatat semua keperluan untuk kegiatan tersebut dengan merinci pemasukan dan pengeluaran.

2. Organisasi nirlaba berbeda dengan organisasi bisnis pada umumnya. Di mana, organisasi nirlaba mendapatkan perolehan dananya dari sumbangan para donatur, dan tidak mengharapkan 
keuntungan yang besar. Pendapatan organisasi nirlaba biasanya didapatkan dari jasa yang berikan seperti memberikan training kepada target yang dituju. Kegiatan dalam organisasi nirlaba sama dengan organisasi bisnis, keduanya sama-sama tidak bisa terlepas dari pertanggungjawaban dana yang digunakan. Untuk itu, organisasi nirlaba juga membutuhkan laporan yang sesuai dengan standar akuntasi keuangan bisnis nirlaba.

Organisasi nirlaba setidaknya harus mencatat dana yang keluar atau pun masuk. Termasuk Ikaboga yang merupakan organisasi sektor publik dimana pelaporan keuangan berpedoman pada PSAK 45. Terkadang memang sulit untuk membuat laporan-laporan tersebut, oleh karena itu setidaknya pengurus organisasi mampu membuat laporan kas keluar dan kas masuk. Aspek akuntabilitas dan transparansi pada organisasi nirlaba menjadi subjek yang sensitif dan komplek. Akuntabilitas dan transparansi organisasi nirlaba menjadi tolak ukur profesionalisme dan kredibilitasnya sebagai sebuah organisasi, terutama bagi organisasi yang bergerak dalam kegiatan non-profit. Akuntabilitas mengacu pada istilah yang luas dan mencangkup beberapa konsep. Secara sederhana, akuntabilitas merupakan bentuk tanggung jawab untuk tindakan yang diambil, mampu memberikan penjelasan dan pemahaman, mengklarifikasi, membenarkan dan menerima tanggungjawab atas tindakan yang diambil. Sedangkan transparansi merujuk pada sikap terbuka, mudah dimengerti, jujur, mudah diakses menggunakan semua media komunikasi. DPC Ikaboga harus melaporkan penggunaan dana karena beberapa anggota terkadang ingin mengetahui penggunaan dana. Dengan melaporkan penggunaan dana dengan mencatat kas masuk maupun kas keluar sudah melakukan aspek akuntabilitas dan transparansi walaupun tidak dengan laporan lengkap.

3. Sebagian masyarakat mungkin belum mengetahui tentang adanya organisasi bersifat nirlaba. Kemunculan organisasi nirlaba sebagai salah satu sektor keuangan di Indonesia merupakan hal yang tabu di masyarakat. Seperti yang diketahui bahwa panti asuhan juga sebagai lembaga non profit memiliki kegiatan manajemen, baik yang berkaitan dengan sumber daya manusia, keuangan dan juga kegiatan operasionalnya. Berdasarkan PSAK 45 karakteristik organisasi nirlaba terutama organisasi seperti Ikaboga berbeda dengan organisasi bisnis. Mengingat adanya tuntutan atas akuntabilitas dan transparansi pada sektor publik serta pentingnya laporan keuangan yang disusun oleh organisasi nirlaba terutama Ikaboga. Dalam PSAK 45 terdapat 4 laporan keuangan yang dibuat yaitu: a) Laporan Posisi Keuangan, yang bertujuan untuk menyediakan informasi mengenai aset, liabilitas dan informasi lainnya;b) Laporan Aktivitas, yang tujuaannya adalah menyediakan informasi mengenai pengaruh transaksi dan peristiwa yang dapat mengubah jumlah dan sifat aset; c) Laporan Arus Kas, bertujuan untuk menyajikan informasi mengenai penerimaan dan pengeluaran kas dalam suatu periode; d) Catatan atas Laporan Keuangan, bertujuan untuk menyajikan segala informasi jumlah dan sifat aset, liabilitas dan aset netto organisasi. Namun untuk DPC Ikaboga Lobar yang memiliki sumber daya yang kurang dalam bidang pencatatan dan pembukuan cukup membuat arus kas masuk dan arus kas keluar setiap peristiwa atau transaksi yang terjadi setiap hari. Salah satu bentuk pertanggungjawaban perusahaan kepada donatur yaitu berupa laporan keuangan. Baik untuk organisasi dalam skala besar maupun dalam skala kecil, laporan keuangan merupakan kewajiban yang harus dibuat pada setiap periode. Jika diibaratkan, laporan keuangan merupakan jantung dari sebuah organisasi. DPC Ikaboga Lobar dapat membuat laporan keuangan sederhana dengan membuat catatan kas masuk dan catatan kas keluar. 

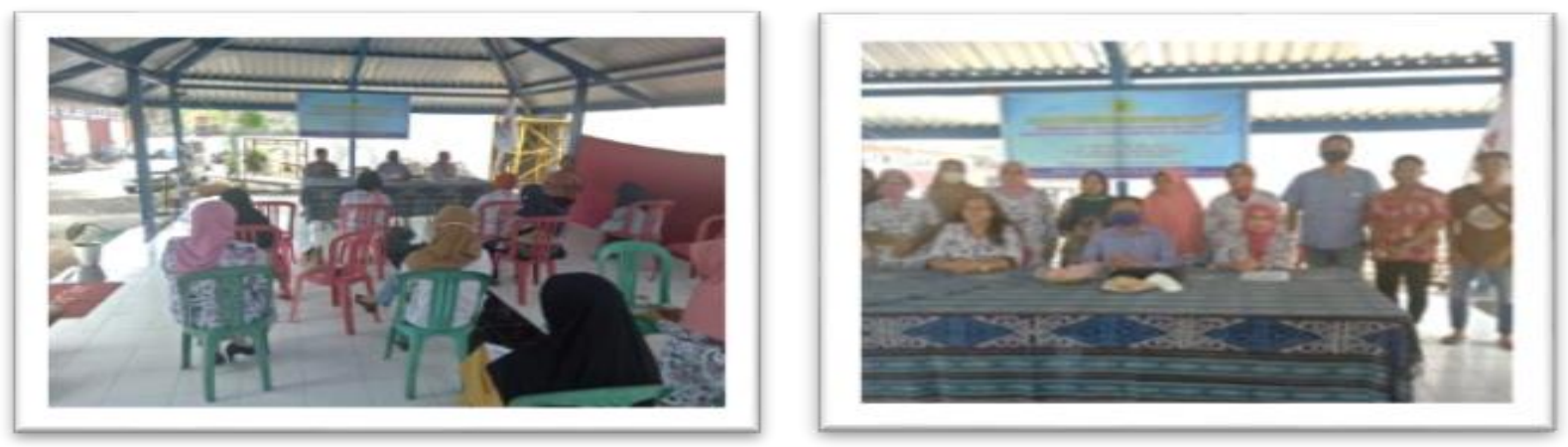

Gambar 1. Kegiatan Pengabdian bagi DPC Ikaboga Kabupaten Lombok Barat

Secara umum kegiatan ini berjalan dengan baik. Adapun indikator untuk menilai keberhasilan kegiatan adalah tingkat kehadiran peserta yang sangat tinggi, animo yang besar untuk mengikuti kegiatan, tanya jawab yang aktif dan interaksi dua arah yang baik selama proses diskusi berlangsung. Sehingga diharapkan kegiatan penyuluhan dan pedampingan penyusunan pengelolaan keuangan tetap dilakukan sehingga memberikan pengetahuan bagi DPC Ikaboga Kabupaten Lombok Barat. Beberapa hal yang masih kurang baik dalam pelaksanaanya akan ditingkatkan pada kegiatan mendatang, yaitu praktik langsung dalam bentuk pencatatan dan pembukuan keuangan Ikaboga.

\section{KESIMPULAN DAN SARAN}

Hasil kegiatan penyuluhan dan pelatihan tentang pembenahan tata kelola Ikaboga DPC Kabupaten Lombok Barat dalam meningkatkan pengetahuan pengurus dan pentingnya dalam pencatatan pembukuan oleh bendahara DPC Lobar. Indikator keberhasilan yang digunakan dalam kegiatan ini yaitu tingkat kehadiran peserta pengabdian yang sangat tinggi, animo yang besar untuk mengikuti kegiatan, tanya jawab yang aktif serta interaksi dua arah yang baik antara tim pengabdian dan peserta selama proses diskusi berlangsung. Oleh karena itu, kegiatan penyuluhan dan pelatihan ini diharapkan selalu dapat dilakukan sehingga membantu memberikan pemahaman yang lebih baik terkait tata kelola organisasi serta pentingnya pengelolaan keuangan. Beberapa hal yang masih kurang baik dalam pelaksanaannya akan ditingkatkan pada kegiatan mendatang, yaitu praktik dalam pencatatan pembukuan dan pembuatan laporan keuangan khusus organisasi nirlaba seperti Ikaboga.

\section{Ucapan Terima Kasih}

Tim pengabdian mengucapkan terima kasih kepada Lembaga Penelitian dan Pengabdian kepada Masyarakat (LPPM), Badan Pengkajian dan Pengembangan Ekonomi dan Bisnis (BP2EB), dan Fakultas Ekonomi dan Bisnis melalui sumber dana BLU (PNBP) Universitas Mataram yang telah memberi kesempatan dan bantuan kepada tim pengabdian untuk melakukan kegiatan ini.

\section{DAFTAR PUSTAKA}

Agus, Dwiyanto. 2006. Mewujudkan Good Geovernance Melalui Pelayanan Public. UGM Press: Yogyakarta.

Bappenas. 2004. Menumbuhkan Kesadaran Tata Kepemerintahan yang baik. Sekretariat Pengembangan Kebijakan Nasional Tata Kepemerintahan yang Baik: BAPPENAS.

Bappenas. 2014. Menumbuhkan Kesadaran Tata Kepemerintahan yang baik. 
Brian, Thompson. 1977. Textbook on Constitutional and Administrative Law, Third Edition (London : Black stone Press Limited, 1977): 353.

Cedric Ryngaert., J. Wouters. 2005. Good Governance lesson from International Organization, First Edition New York. Wessel: 69

Joko, Widodo. 2001. Good Governance (Telaah dan Dimensi Akuntabilitas dan Kontrol Birokrasi Pada Era Desentralisasi dan Otonomi Daerah). Insan Cendekia: Surabaya.

Lembaga Administrasi Negara dan Badan Pengawasan Keuangan dan Pembangunan. 2000. Akuntabilitas Dan Good Goverenance" Lembaga Admnistrasi Negara dan Badan Penagwas Keuangan dan Pembangunan. Jakarta. Halaman 5.

Local Governance Support Program (LGSP). 2002. Pedoman Teknis; Local Governance Assesment IRE. Yogyakarta. 